九州大学学術情報リポジトリ

Kyushu University Institutional Repository

Growth, Development and Reproduction in captive of the Large Japanese Field Mouse, Apodemus speciosus (Rodentia, Muridae)

Oh, Hong Shik

Zoological Laboratory, Faculty of Agriculture, Kyushu University

Mori, Takayuki

Zoological Laboratory, Faculty of Agriculture, Kyushu University

https://doi.org/10.5109/24229

出版情報 : 九州大学大学院農学研究院紀要. 42 (3/4)，pp.397-408，1998-03. Kyushu University バージョン：

権利関係 : 


\title{
Growth, Development and Reproduction in captive of the Large Japanese Field Mouse, Apodemus speciosus (Rodentia, Muridae)
}

\author{
Hong Shik Oh and Takayuki Mōri*
}

\author{
Zoological Laboratory, Faculty of Agriculture, \\ Kyushu University, Fukuoka 812-8581, Japan \\ (Received December 2, 1997 and accepted December 3, 1997)
}

\begin{abstract}
The large Japanese field mice (Apodemus speciosus) were captured and kept in stainless cages under a constant condition at $23^{\circ} \mathrm{C}$ and $14 \mathrm{~L}: 10 \mathrm{D}$ photoperiod, and the growth, development and reproduction were investigated in this species. Modification of feeding condition and nest materials and introduction of a chamber and a running wheel apparatus into each cage first enabled this species to breed under captivity. In our breeding colony, $A$. speciosus produced the pups throughout the year. Concerning sexual maturation of the males, the descended testes and spermiogenesis were observed at 50 days old, copulatory behavior was performed at about 60 days old, and active breeding started at 70-80 days old. On the other hand, in the females, the vaginas opened and mature follicle cells appeared at 60-70 days old at which active breeding began in females. The mean litter size was $4.29(n=27)$, ranging from 3-6, and the gestation period was 19-21 days in this species. Significant sexual difference were detected in each increase in body weight, head and body length, tail length, foot length and ear length. These growth rate constants were similar to each other among the four compared species that belong to genus Apodemus; the Korean striped field mouse, $A$. agrarius chejuensis, the small Japanese field mouse, $A$. argenteus, the Formosan wood mouse, $A$ semotus and the large Japanese field mouse, A. speciosus.
\end{abstract}

\section{INTRODUCTION}

It has been thought that the large Japanese field mouse, Apodemus speciosus, rarely breeds under captivity compared with other rodents, therefore no reliable work pertaining to the large Japanese field mouse has been published, except for fragmentary accounts of the reproduction, growth and development of wild individuals (Murakami, 1974; Miyao et al., 1967; Tateishi and Shiraishi, 1992; Yoshida, 1971). Now we have succeeded in breeding this animal under captivity and obtaining data for its reproduction, growth and development. This study first reports on the housing of captive the large Japanese field mice in our animal quarters. Secondly, we report on the development of male and female reproductive organs, the development of germ cells, age of sexual maturity and finally, the growth and development in $A$. speciosus are also described.

\footnotetext{
* To whom correspondence should be addressed

TEL: 2945(Ext.),E-mail. tmohri@agr. kyushu-u.ac.jp
} 


\section{MATERIALS AND METHODS}

\section{Animals}

In this study, 116 large Japanese field mice from twenty-seven litters were used. They were descendants of nineteen wild mice (nine males and ten females) caught in Fukuoka, Kyushu, Japan in September, 1994. The colony was maintained in a large room, and the mice were housed in $43 \times 25 \times 23 \mathrm{~cm}$ stainless cages (Toyoriko Co., Ltd., Tokyo) containing a chamber with a round entrance at each of the two walls at the corners near the floor. Substantial straw was provided as nest material in each chamber. The animals were maintained in air-conditioned quarters at $23 \pm 1{ }^{\circ} \mathrm{C}$ and $60 \%$ on a $14 \mathrm{~L}: 10 \mathrm{D}$ cycle with lights on at 08:30. Water and food were available ad libitum. The diet consisted of sunflower seeds, flax seeds, peanuts, canary seeds, Chinese, foxtail and Japanese millet seed and laboratory chow (NMF; Oriental Yeast Co., Ltd., Tokyo).

\section{Breeding}

Each mouse was maintained solitarily and a female was introduced into the cage that contained a male in order to facilitate copulation. To determine length of gestation period, thirteen pairs, each composed of one male and one female, were left together for one night (from 20:00 to 09:00 the next day). The gestation period was determined with the pregnant females which were paired in this way. The pregnant females were checked every day, so that newborn pups could be detected within 24 hours after birth. The date of birth was designated as 0 age day and each litter size was recorded at this time. The pups were separated from their mother at 21 days old, at which time the pups had the ability to survive along, and the next parturition occurred if the mother copulated and conceived at the post-parturition estrus.

\section{Observation on reproductive organs}

Observation on development of the reproductive organs was carried out at $0,15,21$, $30,40,50,60,70,80,90$ and 120 days old for both sexes. At each age, two to six males or females were killed with ether, and the testes and caudal epididymides or the ovaries were immediately removed. The testes were weighed fresh using an electric balance (nearest to $0.01 \mathrm{~g}$ ) and their major and minor axis were measured using electric slide calipers (nearest to $0.01 \mathrm{~mm}$ ). The tissues were carefully cut into small pieces with a razor edge in the solution to ensure their fixation. Each tissue was fixed in Bouin's solution, dehydrated in a series of ethanol followed by xylene, and embedded in Paraplast Plus. Sections were cut to a thickness of $4-5 \mu \mathrm{m}$ and stained with Hematoxylin and Eosin. Concerning the males, the process of spermatogenesis or spermiogenesis in the testes and appearance of the sperms in the caudal epididymides were observed under a photomicroscope. Conversely, the vagina of the females was opened and changes in follicle cells in the ovaries at 50,60 and 70 days old were recorded.

\section{Measurements on body weight and four external characteristics}

For the detection of the growth pattern of body weight and the four external characteristics (namely, head and body length, tail length, hind foot length and ear length), 59 pups, 27 males and 32 females, out of the 116 mice raised in our breeding 
colony. Each pup was observed every two days from 0 day to 20 days old, every five days from 20 days to 60 days old and every 10 days from 60 days to 180 days old, and the observation was carried out at 17:00 hours. The asymptotic value, growth rate constant and age at the inflection point were estimated by fitting values, obtained from 0 day to 180 days old, to the Gompertz sigmoidal equation (Zullinger et al., 1984).

\section{Observation on major developmental events}

The developmental events were recorded every day until 22 days old. We recorded the ages on days at which the following changes occurred: erecting of ear pinnae, covering of back or abdomen with fur, erupting of upper or lower incisors, opening of auditory meatus and eyes.

\section{RESULTS}

\section{Reproductive parameters}

\section{Litter size}

The large Japanese field mice produced pups throughout the year. One hundred sixteen pups from 27 litters were raised by the eight females in total (Table 1). The most frequently observed litter size was four to five, and the mean litter size was $4.29 \pm 0.82$ $(\bar{x} \pm S D$; range of three to six). The mean litter size of $\mathrm{F} 1$ individuals reared by the wild mice were $4.14 \pm 0.69$ ( $\bar{x} \pm S D ; n=7$; range of three to five). The mean litter size of F2 individuals was $4.41 \pm 0.99(\bar{x} \pm S D ; n=12$; range of three to five). and that of $F 3$ individuals was $4.25 \pm 0.70(\bar{x} \pm S D ; n=8$; range of three to five). The sex ratio at birth was 1:0.93 (60 males and 56 females) and no sexual difference was detected in number at birth. The youngest mother of the all females that successfully gave birth to the pups was 73-days-old and the oldest one was 507-days-old. Of the 13 pairs left for one night, eight pairs produced and reared their young. Moreover, the estimated gestation period was 19-21 days in this species. Continuous parturition by one female occurred at a 21 to 35 day interval, in which most dams gave birth to their litters at a 25 to 30 day interval. In addition to this, the longest life span was 802 days in males and 817 days in females under captivity.

Table 1. Litter sizes among 8 females from three generations of Apodemus speciosus.

\begin{tabular}{|c|c|c|c|c|c|c|c|}
\hline \multirow{2}{*}{ Generation } & \multicolumn{4}{|c|}{ Litter size } & \multirow{2}{*}{$\begin{array}{l}\text { Total } \\
\text { no.of } \\
\text { litters }\end{array}$} & \multirow{2}{*}{$\begin{array}{c}\text { Total } \\
\text { no.of } \\
\text { youngs }\end{array}$} & \multirow{2}{*}{$\begin{array}{c}\text { Mear } \\
\text { litter size } \\
\pm S E\end{array}$} \\
\hline & 3 & 4 & 5 & 6 & & & \\
\hline $\mathrm{F}^{*} *$ & 1 & 4 & 2 & & 7 & 29 & $4.14 \pm 0.69$ \\
\hline $\mathrm{F} 2$ & 2 & 5 & 3 & 2 & 12 & 53 & $4.41 \pm 0.99$ \\
\hline F3 & 1 & 4 & 3 & & 8 & 34 & $4.25 \pm 0.70$ \\
\hline Total & 4 & 13 & 8 & 2 & 27 & 116 & $4.29 \pm 0.82$ \\
\hline
\end{tabular}

* F1 represents wild mice which were paired and allowed to copulate in the laboratory. 


\section{Sexual maturation}

The longest major axis of the all testes at birth was $2.22 \mathrm{~mm}$ and the longest minor axis was $1.23 \mathrm{~mm}$. The longest major axis and minor axis reached $11.54 \mathrm{~mm}$ and $6.02 \mathrm{~mm}$ at 45 days old, respectively (Table 2). At 50 days old, each of both lengths of their testes was $12.66 \mathrm{~mm}$ and $6.74 \mathrm{~mm}$ respectively, and the descended testes and spermiogenesis were first observed (Fig. 1). In the testes of the 60-day old males, the longest major axis

Table 2. Postnatal development of testis and perforation of the vaginal orifice in Apodemus speciosus.

\begin{tabular}{crccc}
\hline Age in days* & BW(g) & TS $(\mathrm{mm})$ & Sperm & PVO \\
\hline 0 & $2.43 ; 2.44$ & $1.07 \times 2.13 ; 1.23 \times 2.22$ & - & - \\
15 & $10.12 ; 10.43$ & $2.74 \times 5.19 ; 2.92 \times 5.65$ & - & - \\
21 & $15.24 ; 15.79$ & $3.28 \times 6.27 ; 3.33 \times 6.48$ & - & - \\
30 & $21.67 ; 22.04$ & $5.18 \times 9.24 ; 5.44 \times 9.47$ & - & - \\
40 & $28.43 ; 29.02$ & $5.98 \times 11.24 ; 6.02 \times 11.54$ & - & - \\
50 & $32.14 ; 33.47$ & $6.67 \times 12.57 ; 6.74 \times 12.66$ & - & - \\
60 & $35.19 ; 36.15$ & $6.94 \times 13.11 ; 6.96 \times 13.49$ & - & + \\
70 & $37.29 ; 38.19$ & $7.24 \times 13.46 ; 7.29 \times 14.16$ & + & + \\
80 & $39.14 ; 39.97$ & $7.87 \times 14.58 ; 7.89 \times 15.14$ & + & + \\
90 & $40.48 ; 41.28$ & $8.14 \times 15.44 ; 8.54 \times 16.07$ & + & + \\
120 & $43.26 ; 44.05$ & $8.81 \times 15.56 ; 8.89 \times 16.43$ & + & + \\
\hline
\end{tabular}

* Two individuals were measured from each age group. BW, body weight; TS, testis size in minor $\times$ major axis. Sperms in the caudal epididymides: - , absence; + , presence; PVO, perforation of the vaginal orifice: - , intact; + , perforated.

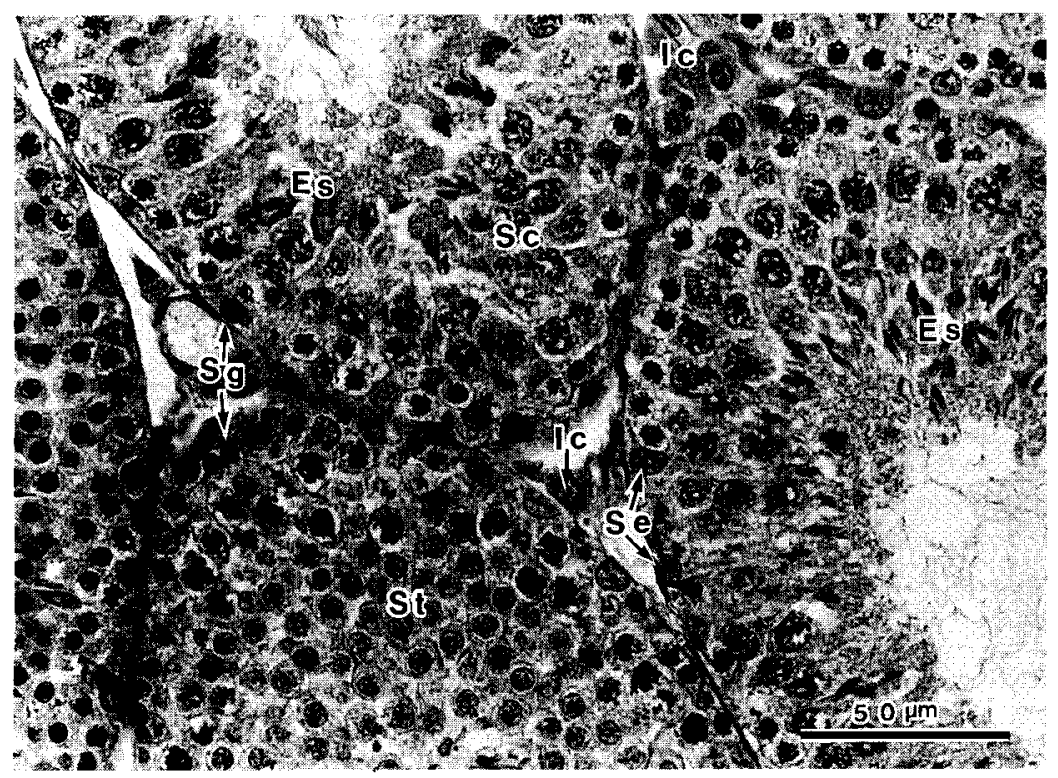

Fig. 1. Photograph of seminiferous tubules of the testis in Apodemus speciosus at 50 days old. Es; Elongated spermatids; Ic, interstitial cells; Sc, spermatocytes; Se, Sertoli cells; Sg, spermatogonia; St, spermatids. 


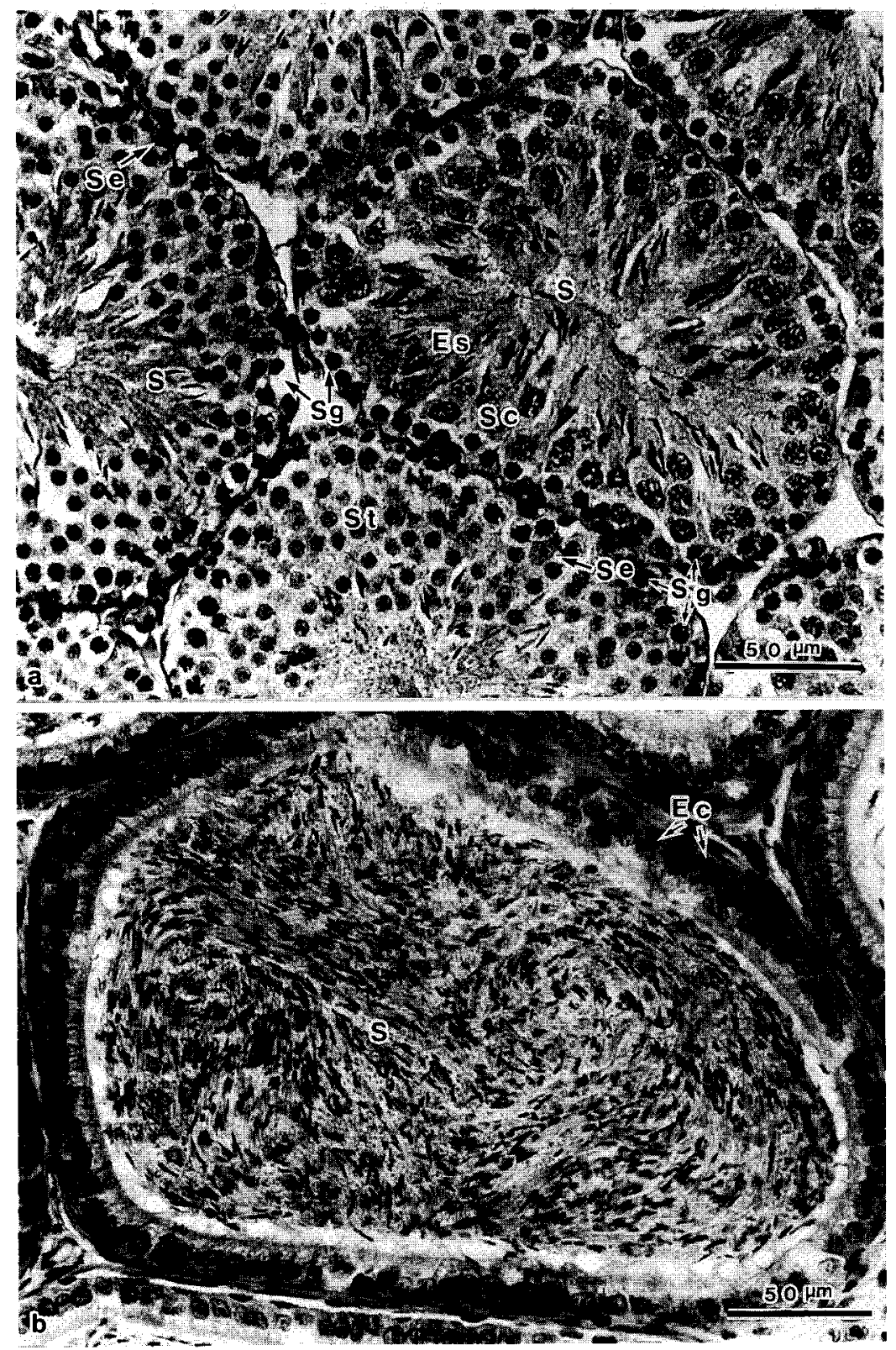

Fig. 2. Photographs of the testis and caudal epididymis in Apodemus speciosus at 70 days old. a) Spermatogenesis in seminiferous tubules, and b) the caudaepididymal tubules with numerous sperm in cross section. Ec, epithelial cells; Es; Elongated spermatids; S, spermatozoa; Sc, spermatocytes; Se, Sertoli cells; Sg, spermatogonia; St, spermatids. 


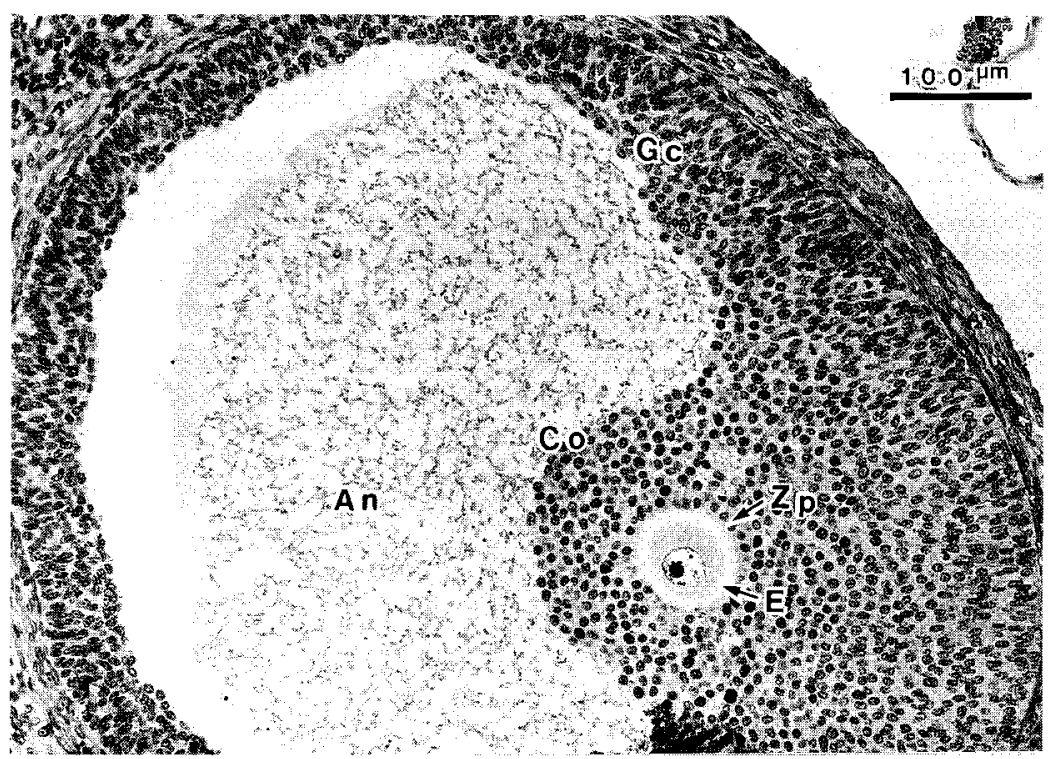

Fig. 3. Photograph of the ovary in Apodemus speciosus at 60 days old. Graafian follicle with a developed antrum (An). Co, cumulus oophorus; E, egg; Gc, granulosa cells; Zp, zona pellucida.

of the testes was $13.49 \mathrm{~mm}$ and the longest minor axis was $6.96 \mathrm{~mm}$, with a few sperm first appearing in the caudal epididymides. Afterwards, at 70 days old, the longest major axis was $13.49 \mathrm{~mm}$, and the spermiogenesis occurred more frequently (Fig. 2a), and sperm was observed abundantly in the caudal epididymides (Fig. 2b). On the other hand, in the females, the vagina opened and five to six mature follicles were found in their ovary at 60 days old (Fig. 3). This species had spontaneous ovulation in which the estrus cycle revolved once every 4-6 days. Both ovaries were functional, but the right one performed better. The right ovary had 5.6 mature follicles and 4.2 corpora lutea, and the left contained 4.6 mature follicles and 3.8 corpora lutea. Moreover, 3.8 fetuses were detected in the right ovary and 3.6 fetuses in the left ovary.

\section{Growth patterns}

Obtained values from the day of birth to 180 days postpartum for body weight and the four external characteristics were analyzed by the Gompertz equation.

\section{Body weight}

At birth, no significant sexual difference was detected and the mean body weight of both sexes was $2.41 \pm 0.23 \mathrm{~g}$. The first significant sexual difference was detected at 40 days old, and the mean value continued to raise until $28.37 \pm 1.17 \mathrm{~g}$ in males and $25.17 \pm$ $0.84 \mathrm{~g}$ in females. The difference between both sexes was most noticeable at 60 days old, each value respectively reaching $36.13 \pm 1.23 \mathrm{~g}$ in males and $30.99 \pm 0.75 \mathrm{~g}$ in females (Fig. 4). The growth rate thereafter reduced gradually, and the mean body weight continued increasing until 120 days old in males at which time the mean was $43.03 \pm 1.07 \mathrm{~g}$. It also kept increasing in females until 100 days old at which time the mean body weight of 


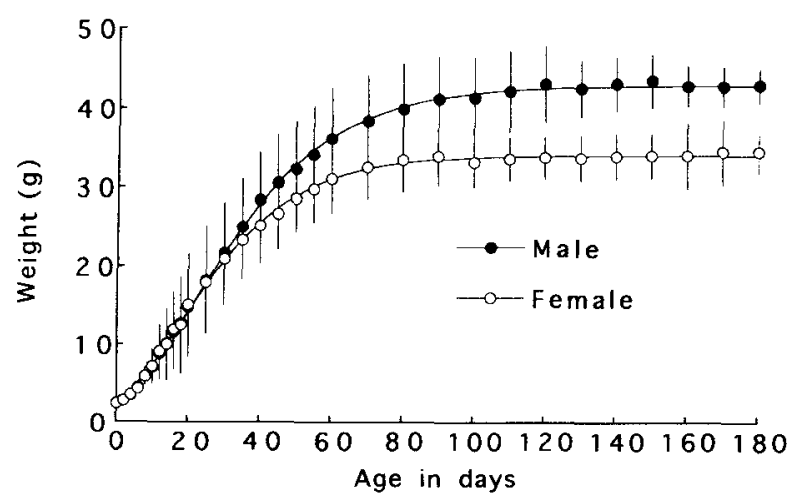

Fig. 4. Growth curves in the body' weight of Apodemus speciosus. Lines portray growth curves predicted by the Gompertz equation.

Table 3. Coefficient (mean $\pm S E$ ) of the Gompertz equation for body weights and four characteristics in Apodemus speciosus

\begin{tabular}{|c|c|c|c|c|}
\hline & \multirow[b]{2}{*}{ Sex } & \multicolumn{3}{|c|}{ Coefficients } \\
\hline & & A & $\lambda$ (/days) & $\mathrm{ti}$ \\
\hline \multirow[t]{2}{*}{ Body weight(g) } & $0^{\lambda}$ & $42.89 \pm 0.13$ & $0.0471 \pm 0.0005$ & $22.19 \pm 0.17$ \\
\hline & 오 & $33.99 \pm 0.12$ & $0.0561 \pm 0.0009$ & $17.58 \pm 0.20$ \\
\hline Head and body & $\pi$ & $107.96 \pm 0.45$ & $0.0516 \pm 0.0014$ & $1.97 \pm 0.31$ \\
\hline length(mm) & 우 & $100.81 \pm 0.45$ & $0.0611 \pm 0.0019$ & $1.30 \pm 0.33$ \\
\hline \multirow[t]{2}{*}{ Tail length(mm) } & $d$ & $92.48 \pm 0.56$ & $0.0653 \pm 0.0021$ & $10.63 \pm 0.29$ \\
\hline & 우 & $90.76 \pm 0.56$ & $0.0723 \pm 0.0025$ & $9.39 \pm 0.29$ \\
\hline \multirow{2}{*}{$\begin{array}{l}\text { Hind foot length } \\
\text { (mm) }\end{array}$} & $\delta$ & $24.71 \pm 0.13$ & $0.0961 \pm 0.0037$ & $3.41 \pm 0.27$ \\
\hline & 오 & $24.31 \pm 0.11$ & $0.0981 \pm 0.0035$ & $3.06 \pm 0.25$ \\
\hline \multirow[t]{2}{*}{ Ear length(mm) } & $\delta$ & $16.37 \pm 0.05$ & $0.1035 \pm 0.0031$ & $5.15 \pm 0.20$ \\
\hline & 우 & $16.18 \pm 0.05$ & $0.1035 \pm 0.0031$ & $5.34 \pm 0.20$ \\
\hline
\end{tabular}

A, asymptotic values; $\lambda$, growth rate constants; ti, age at the inflection points.

females was $33.74 \pm 0.61 \mathrm{~g}(t=19.833, p<0.0001)$. The asymptotic weight for males was found to be $42.89 \pm 0.13 \mathrm{~g}$ and for females $33 . \pm 0.12 \mathrm{~g}$, according to the Gompertz equation for the body weight (Table 3 ). The mean body weight at sexual maturation was $38.29 \pm 1.14 \mathrm{~g}$ in males and $30.99 \pm 0.75 \mathrm{~g}$ in females.

\section{Head and body length, tail length, hind foot length, ear length and tail ratio}

No significant sexual difference was detected at birth for head and body length, and the mean length of both sexes was $34.11 \pm 1.42 \mathrm{~mm}$. A significant sexual difference was found from 50 days old onward, and at this time, each mean head and body length was $97.34 \pm 1.15 \mathrm{~mm}$ in males and $93.35 \pm 0.76 \mathrm{~mm}$ in females, respectively. By 90 days old, each mean value reached $106.59 \pm 0.95 \mathrm{~mm}$ in males and $99.66 \pm 0.78 \mathrm{~mm}$ in females, respectively and thereafter the growth rate in head and body length slowly decreased. In a similar way, for the tail length, no significant sexual difference was detected at birth, 

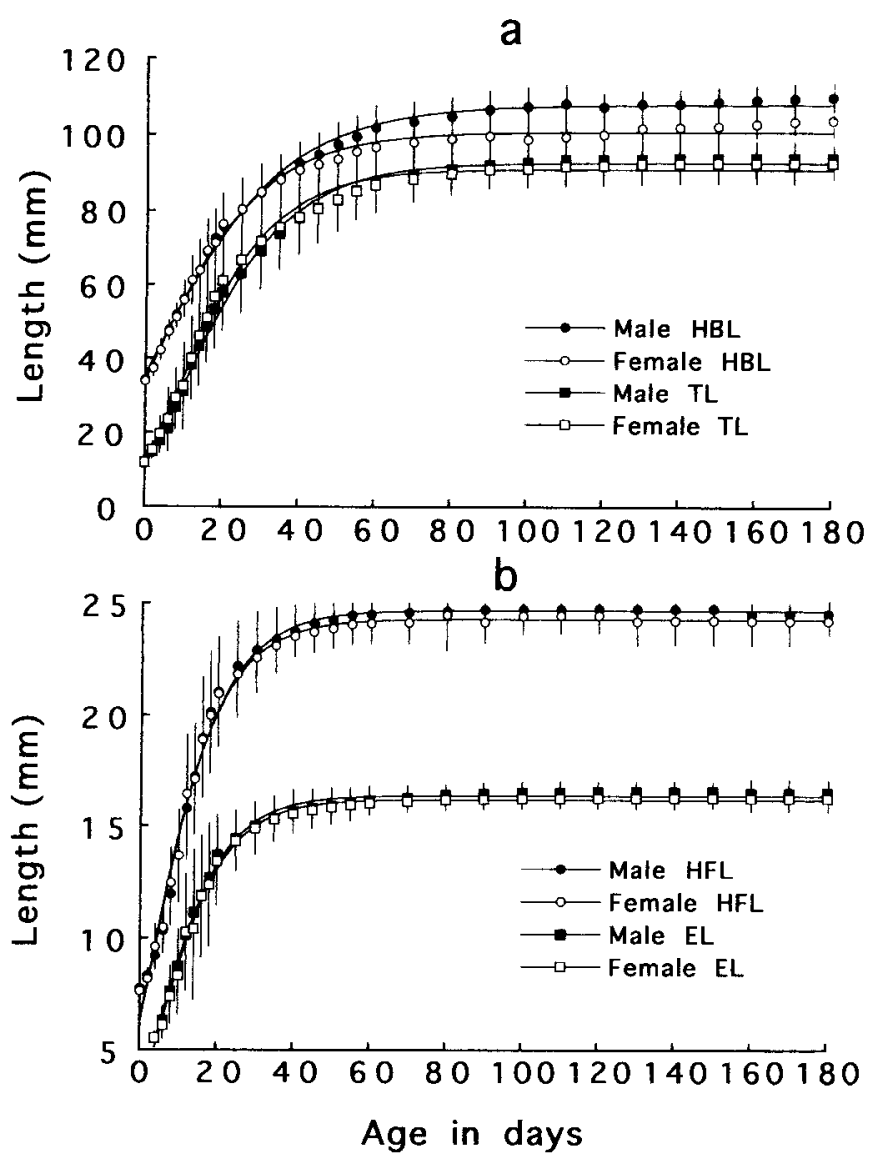

Fig. 5. Growth curves; a) the head and body length (HBL) and tail length (TL); b) hind foot length (HFL) and ear length (EL) of Apodemus speciosus. Lines portray growth curves predicted by the Gompertz equation.

and the mean tail length of both sexes was $11.95 \pm 0.65 \mathrm{~mm}$. The mean length of the tails in males and females reached $77.84 \pm 1.69 \mathrm{~mm}$ and $78.27 \pm 1.81 \mathrm{~mm}$, respectively by 40 days old. Both mean tail length increased until 80 days old, at which time each mean value was $90.68 \pm 1.06 \mathrm{~mm}$ in males and $89.58 \pm 0.94 \mathrm{~mm}$ in females and almost ceased raising (Fig. 5a). Concerning foot length, there was also no significant sexual difference detected at birth. The mean tail length of the 0 -day old pups of both sexes was $7.65 \pm$ $0.37 \mathrm{~mm}$. The mean value thereafter raised rapidly and reached $21.03 \pm 0.49 \mathrm{~mm}$ in males and $20.97 \pm 0.41 \mathrm{~mm}$ in females by 20 days old. The following dilatory growth of $23.40 \pm$ $0.28 \mathrm{~mm}$ in males and $23.12 \pm 0.22 \mathrm{~mm}$ in females continued until 35 days old when the mice reached adult size. For the ear length, the mean value increased drastically from 4 days of old onwards at which time the mean value of both sex was $5.54 \pm 0.22 \mathrm{~mm}$, and the 
sexual difference became significant at 25 days old, at which time each mean value reached $14.42 \pm 0.25 \mathrm{~mm}$ in males and $14.32 \pm 0.24 \mathrm{~mm}$ in females, respectively. At 40 days old, the mean ear length was $15.64 \pm 0.64 \mathrm{~mm}$ in males and $15.54 \pm 0.15 \mathrm{~mm}$ in females, and both mean values increased to the adult value for each sex (Fig. 5b). A significant difference was detected between both sexes for all of the four external characteristics, namely head and body length $(t=14.532, p<0.001)$, tail length $(t=3.028$, $p<0.001)$, hind foot length $(t=3.033, p<0.001)$ and ear length $(t=4.678, p<0.001)$. In addition, the mean tail ratio became dramatically greater by age 50 days in both sexes. The increase in mean tail ratio remained the same until 90 days and no significant sexual difference was detected $(p<0.001)$. Each asymptotic value was assessed based on the Gompertz equation at $107.96 \pm 0.45 \mathrm{~mm}$ in males and $100.81 \pm 0.45 \mathrm{~mm}$ in females for head and body length, $92.48 \pm 0.56 \mathrm{~mm}$ in males and $90.76 \pm 0.56 \mathrm{~mm}$ in females for tail length, $24.62 \pm 0.07 \mathrm{~mm}$ in males and $24.24 \pm 0.08 \mathrm{~mm}$ in females for hind foot length, and $16.37 \pm 0.05 \mathrm{~mm}$ in males and $16.16 \pm 0.05 \mathrm{~mm}$ in females for ear length (Table 3 ).

\section{Developmental events}

In newborn pups of $A$. speciosus at birth, the body was naked where no hair was detected, the eyes completely closed, black pigment observed on the eyelids, and each digit of hands and feet was totally conglutinated together to the tip. Afterwards, fur was erupted on the back at $2.7 \pm 0.5$ days old, the digits of the hands began separating at $2.7 \pm$ 0.6 days old, the ears were erect at $3.0 \pm 0.4$ days old, and the digits of hands and feet were separated completely at $4.5 \pm 0.5$ days old and $5.4 \pm 0.5$ days old respectively (Fig. 6). The lower and upper incisors erupted at 10.8 \pm 0.8 days old and $11.5 \pm 0.7$ days old respectively, and afterwards the eyes opened at $12.6 \pm 0.6$ days old followed by opening of the auditory meatus at $11.6 \pm 0.6$ days old. The pups initiated consumption of solid food at 14 days old and the weaning occurred at 20-25 days old. Adult-like fur emerged at 35 days old, and the fur was completely replaced with adult-like fur at 50 days old.

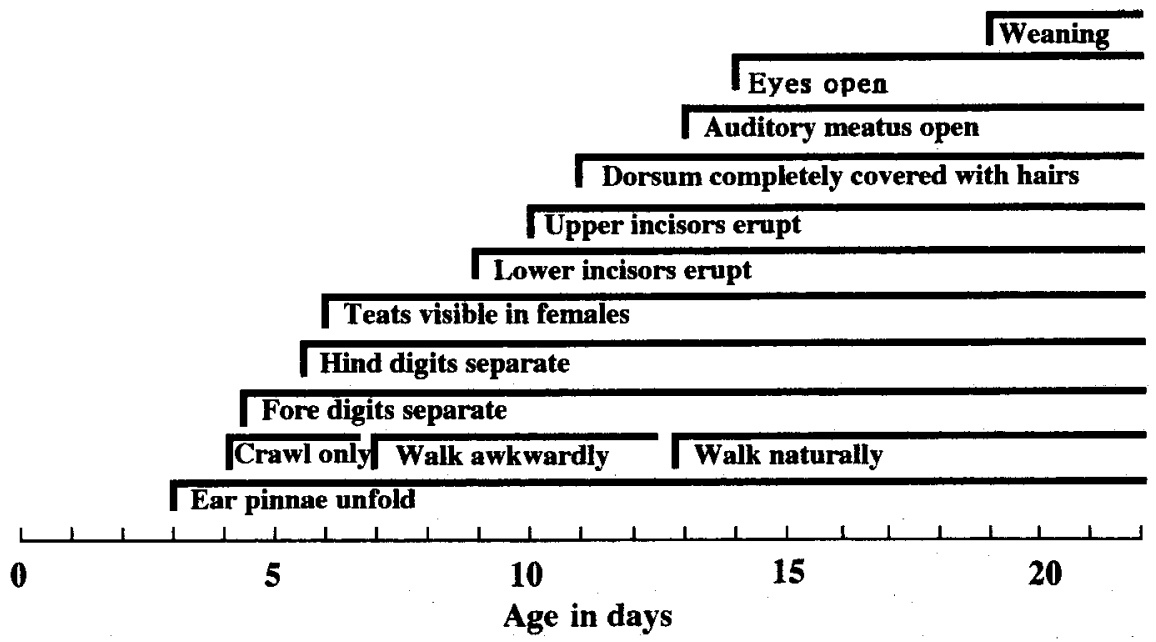

Fig. 6. Diagram showing the principal events during the postnatal development of Apodemus speciosus. 


\section{DISCUSSION}

Although the condition of the light is thought to be one of the most significant factors which impact reproduction under captivity in most species that reproduce seasonally in the wild, the temperature influences most efficiently in the large Japanese field mouse (Murakami, 1974). According to another report, the condition of the air at $14-23^{\circ} \mathrm{C}$ in which the temperature alters at a difference of $5-7^{\circ} \mathrm{C}$ a day which allows this species to breed under captivity (Tsuchiya, 1979). In spite of these facts, in our study, the large Japanese field mouse produced its young under a constant air condition. This suggests that a chamber used as the nest and the modified nest materials and feeding condition, not alteration of the temperature, is necessary for reproduction under captivity in this species. Moreover, some authors report that body weight tends to become heavier in breeding season than in non-breeding season in wild rodents (Lin and Shiraishi, 1992; Yoon et al., 1997; Yoshinaga et al., 1997). In our A. speciosus, breeding colony changes in body weight were not observed, and the captive mice were as likely to maintain constant body weight throughout a year as the body weight of the wild individuals in the breeding season (approximately $40 \mathrm{~g}$ in males and $32 \mathrm{~g}$ in females). In addition, there was an additional increase in body weight of the males as they were breeding (44-53 g). Thus the increase in body weight of the males seems to reflect the reproductive condition. Feeding on sunflower seeds, peanuts, flax seeds, canary seeds, Chinese, foxtail and Japanese millet seeds added to laboratory chow facilitated the continuous breeding of $A$. speciosus under captivity. In order to reduce stress on these mice and to prevent them from storing extra lipid in the body, a running wheel apparatus in which the mouse could run by turning the wheel was placed in the cages. Also, substantial straw provided as nest material seems to have contributed to the animal's breeding. In addition, the field mouse was housed alone and the female was put into the male's cage. In suncus, Suncus murinus, this method is often used in order to facilitate copulation (Clenendon and Rissman, 1990; Bedford et al., 1997). Under captivity, the mean litter size in this species (4.29 \pm 0.82$)$ was small compared to that in the Korean striped field mouse, A agrarius chejuensis (4.76 from Oh and Mōri, in press) but was similar to that in the wood mouse, A. sylvaticus (4.2 from Clarke, 1985), and the Formosan wood mouse, A. semotus (4.29 from Lin et al., 1993).

In the young large Japanese field mouse raised in our breeding colony, significant sexual differences were detected at nearly 40 days old for body weight, head and body length and tail length, although the testes had not descended yet at this time. The descended testes and spermiogenesis were observed at 50 days old at which time a few sperm appeared in the caudal, and the major axis increased to $12.66 \mathrm{~mm}$. Copulation first occurred at about 60 days old and active breeding began between 70 and 80 days old. Hence, the full-scale breeding age started the descendent of the testes after 20 days following and the first superciliousness in males large Japanese field mouse. In almost all of the females individuals, perforation of the vaginal orifice was between 60 and 70 days old, at which time the active breeding started. Under captivity, the females was capable of breeding at 70 days old. The gestation period was 19-21 days. The continuous parturition occurred at 25-30 day intervals (mean $=27.1$ days), and the oldest individual of all the females which gave birth to the pups produce its young at 507 days old, and the 
Table 4. Comparison of developmental traits and growth of both sexes combined, before the weaning stage, among four Apodemus species.

\begin{tabular}{|c|c|c|c|c|c|c|c|}
\hline \multirow{2}{*}{ Species } & \multicolumn{4}{|c|}{ Developmental traits } & \multicolumn{2}{|c|}{ Growth } & \multirow{2}{*}{ References } \\
\hline & $\mathrm{EP}$ & $\begin{array}{l}\text { ELI } \\
\text { (in d }\end{array}$ & $\begin{array}{l}\text { OAM } \\
\text { ays) }\end{array}$ & $\mathrm{OE}$ & $\begin{array}{l}\text { WB } \\
\text { (g) }\end{array}$ & $\begin{array}{c}\mathrm{K} \\
\text { (/day) }\end{array}$ & \\
\hline Apodemus speciosus & $3-4$ & $9-10$ & $11-12$ & $12-14$ & 2.4 & 0.049 & Present work \\
\hline A. agrarius & $2-3$ & $9-10$ & $12-13$ & $10-11$ & 2.4 & 0.047 & Oh \& Mōri (in press) \\
\hline \multirow[t]{2}{*}{ A. argenteus } & $3-4$ & $10-12$ & $11-12$ & $12-14$ & 1.7 & 0.059 & Fujimaki (1978) \\
\hline & $2-3$ & 8 & 12 & $12-14$ & & & Koyama (1994) \\
\hline A. semotus & $2-3$ & $9-10$ & $12-14$ & $14-16$ & 2.1 & 0.042 & Lin et al. (1993) \\
\hline
\end{tabular}

$\mathrm{Ep}$, erection of ear pinnae; ELI, eruption of lower incisors; OAM, opening of auditory meatus; $\mathrm{OE}$, opening of eyes; $\mathrm{WB}$, weight at birth; $\mathrm{K}$, growth rate constants.

mean litter size was 4.29. These results demonstrate that one female A. speciosus can product around 70 young mice at maximum during its life.

As observed in A. semotus (Lin et al,, 1993), small Japanese field mouse, A. argenteus (Koyama, 1994) and A. a. chejuensis (Oh and Möri, in press ), the body weight, head and body weight and tail length dramatically increased until 40 days old, and the foot length and ear length rapidly raised until 30 days old in $A$. speciosus, though individual growth in the body weight and the characteristics continued till later in life, reducing the growth rate. Notably, both growth rates for foot length and ear length were twice as large as those for body weight, head and body length and tail length, and both inflection points for foot length and ear length in A. speciosus, which was 3.2 days for foot length and 5.2 days for ear length, respectively. They were also earlier compared with those in the other species of genus Apodemus. These results suggest an earlier achievement of active locomotion and thus these larger growth rates, and earlier inflection points for the foot length and the ear length characterize $A$. speciosus. No difference was detected among the four species mentioned above for the age at which ear pinnae erection was observed, lower incisors erupted and auditory meatus opened, although $A$. speciosus develops more rapidly than both of $A$. a. chejuensis and $A$. semotus but more slowly than $A$. argenteus, according the calculated growth rate constant (Table 4). Moreover, the inflection point for the body weight in A. speciosus was 22.2 days in the males and 17.5 days in the females, and at this time, they were weaned. In most rodents, it is not possible to estimate the inflection point for body weight from the growth rate constant and the asymptotic value, and the inflection point and weaning does not necessarily coincide (Zullinger et al., 1984). The genus Apodemus species may thus be characterized by the coincidence of the inflection point and the day of weaning.

\section{REFERENCES}

Bedford, J. M., T. Mori and S. Oda 1997 Ovulation induction and gamete transport in the female tract of the musk shrew, Suncus murinus. J. Reprod. Fert., 110: 115-125

Clarke, J. R. 1985 The reproductive biology of the bank vole (Clethrionomys glareolus) and the wood mouse (Apodemus sylvaticus). Symp. zool. Soc. Lond., 55: 33-59

Clenendon, AL and EF. Rissman 1990 Prolonged copulatory behavior facilitates pregnancy success in the musk shrew. Hormones \& Behavior, 25: 125-127 
Fujimaki, Y. 1978 Postnatal growth and development of Apodemus argenteus. J. Mamm. Soc. Japan, 7: $135-142$

Koyama, S. 1994 On the growth and development Apodemus argenteus under laboratory conditions. Honyurui Kagaku, 33: 109-122

Lin, L-K. and S. Shiraishi 1992 Reproductive biology of the Formosan wood mouse, Apodemus semotus. J. Fac. Agr., Kyushu Univ., 36: $183-200$

Lin, L-K., T. Nishino and S. Shiraishi 1993 Postnatal Growth and Development of the Formosan wood mouse, Apodemus semotus. J. Mamm. Soc. Japan, 18: 1-18

Miyao, T., T. Morozumi and M. Morozumi 1967 Small Mammals of Mt. Yatsugatake, Honshu. VII. Seasonal change in reproduction of the wood mouse, Apodemus speciosus. Zoological Magazine, 76: 161-166

Murakami, O. 1974 Growth and development of the Japanese wood mouse (Apodemus speciosus). I. The breeding season in the field. Japan J. Ecol., 24: 194-206 (in Japanese with English synopsis)

Shioya, S. 1994 Comparative studies of food habits and digestive tracts in two Apodemus species. $J$. Fac. Agr., Kyushu Univ., 38: 243-254

Tateishi, T. and S. Shiraishi 1992 Distribution and reproductive activity of the Japanese large field mouse. Sci. Bull. Fac. Agr., Kyushu Univ., 47: 85-92 (in Japanese with English abstract)

Tsuchiya, K. 1979 A contribution to the chromosome study in Japanese mammals. Proc. Japan Academy, 55(B): 191-195

Yoon, M. H., S. J. Jung and H. S. Oh 1997 Studies on population structure and reproductive pattern of the Korean striped field mice, Apodemus agrarius. Korean J. Biol. Sci., 1: 53-61

Yoshida H. 1971 Small mammals of Mt. Kiyomizu, Fukuoka Pref. 3. Reproduction in the Japanese wood mouse, Apodemus speciosus. J. Mamm. Soc. Jpn., 5: 123-129

Yoshinaga, Y., T. Okayama, T. Mori and S. Shiraishi 1996 Estimation of seasonally changing growth curves in wild Japanese field voles, Microtus montebelli. J. Fac. Agr., Kyushu Univ., 41: 189-196

Zullinger, E. M., R. E. Ricklefs, K. H. Redford and G. M. Mace 1984 Fitting sigmoidal equations to mammalian growth curves. J. Mammal., 65: 607-636 